\title{
9. The education revolutionary road: paved with good intentions
}

\section{CAROLE KAYROOZ AND STEPHEN PARKER}

Kevin Rudd promised an 'education revolution', to widespread acclaim and almost no opposition. In this analysis, we argue that Rudd's education policy was paved with good intentions to redress long-term deficiencies inherited largely from the Howard years. In many respects, however, the policy lacked the strategic and structural blueprint needed to realise its underlying ideals. The lack of a coherent educational framework informed by a deep knowledge of the Australian educational sector created conflicting policy agendas, some confused objectives and a lack of focus. The unexpected advent of the global financial crisis (GFC) precipitated one of the fastest surges of spending on education in Australia's recent history, but hurried and uncoordinated consultation and implementation processes led to some publicly damaging outcomes. These ultimately played a role in undermining the confidence of the Australian public and also Rudd's own party. As we enter a new administration headed by Julia Gillard, the former Minister for Education, it remains to be seen whether the education revolution will lead to the fundamental systemic transformation implicit in the word 'revolution'.

\section{Rudd's intentions for prosperity, productivity growth and human capital investment}

In the Labor Party's educational election platform, The Australian Economy Needs an Education Revolution, Kevin Rudd and Stephen Smith (then Shadow Minister for Education and Training) continued Howard's framing of education as an economic good; however, they raised and vehemently challenged the Howard government's under-investment. In 2007, Australia's overall investment in education was 5.8 per cent of GDP-behind 17 other leading economies, including the United States, Britain, New Zealand and Poland. They argued that with the rise of China and India, Australia's 'only future was in a long-run national strategy that enshrined education as the driver of productivity and 
prosperity'. This would require a 'revolution in the quantity of our investment in human capital and in the quality of outcomes that the education system delivers'. Aiming to make Australia a 'competitive, innovative, knowledge based economy', the intent was to overhaul the entire national education system from early childhood to mature-age learning. The unifying theme would be education as the engine of the economy. Education would drive productivity, and productivity would bring prosperity (Rudd and Smith 2007:27). This logic was strongly reflected in the creation of a mega-ministry under the deputy leader of the government, Julia Gillard, which comprised education, employment and workplace relations. Gillard was informally referred to as the 'Minister for Productivity', and under the program of the Council of Australian Governments (COAG) an expansive agenda was established under a Productivity Working Group chaired by Gillard.

In examining Rudd's first-term legacy, this analysis focuses in turn on the school and tertiary sectors where significant reform was initiated. In the vocational education sector, reform through COAG was attempted but only modest changes were realised, and then largely in the context of an imploding overseas student market, which had followed a number of violent attacks against Indian students in Australia. The chapter tracks progress against the objectives for the education revolution, drawing comparisons with the educational achievements of Blair's first term in the United Kingdom and, to a lesser extent, with the United States. Both countries informed much of the thinking underpinning Labor policy. It will be argued that contrary to Labor's insistence on local, evidence-based policy, these sources show that much Labor policy was derivative and largely unsupported by any Australian-based research.

\section{The school sector: revolution or evolution?}

The GFC precipitated one of the fastest spending sprees on education in the nation's recent history. In 2009-10, the states received \$19.4 billion in Specific Purpose Payments from the Commonwealth to support state education servicesan increase of 64.4 per cent compared with the $\$ 11.8$ billion the states received in 2008-09. In addition, further funding was allocated as part of the federal finances reform package agreed by COAG in November 2008, the Commonwealth and states/territories reform based on National Partnership Agreements relating to the Smarter Schools Program for Quality Teaching (\$550 million), Low SES (socio-economic status) School Communities (\$1.5 billion), literacy and numeracy, and the Productive Places programs (Australian Government 2010). It included the funding announced under the 'computers in schools' Digital Education Revolution (DER) program. 
The school infrastructure programs were massive, comprising: Building the Education Revolution (BER), Trade Training in Schools and the DER. The government committed to spending $\$ 16.2$ billion for building or upgrading all of Australia's government and non-government schools (DEEWR 2010a) as part of the $\$ 42$ billion Nation Building Economic Stimulus package. As part of the DER, it provided $\$ 2.2$ billion over six years for new information technology (IT) equipment for all secondary schools with students in years nine to 12 (the National Secondary School Computer Fund); the deployment of high-speed broadband connections to Australian schools; new and continuing teacher training in the use of information and communications technology (ICT) (DEEWR 2010b); and online curriculum tools and resources. The Trade Training Centres in Schools provided $\$ 2.5$ billion over 10 years to enable all secondary schools to apply for funding up to $\$ 1.5 \mathrm{~m}$ for Trade Training Centres (DEEWR 2010c). Other system-wide initiatives included the development of the national curriculum for kindergarten to year 12 by means of the Australian Curriculum, Assessment and Reporting Authority (ACARA) and the development of the 'My School' web site (ACARA 2010) to encourage transparency in school performance data, reporting and assessment.

The first of these, and by far the biggest, the BER, was a rushed response, in part to avert the collapse of the building industry following the GFC. The pace was extraordinary. Within six months of the announcement, the Department of Employment, Education and Workplace Relations (DEEWR) had approved projects for about 8000 schools (DEEWR 2010d; O'Keefe 2010). By 2010, all BER funding was allocated for each of its three elements: \$14.1 billion for 7961 primary schools covering 10665 projects including new libraries, classrooms and refurbishment; \$821.8 million for Science and Language Centres (SLCs) in 537 schools for the construction or refurbishment of existing science laboratories or language learning centres; and \$1.28 billion for the National School Pride (NSP) program to 9497 schools for 13047 projects including refurbishment or construction of buildings and sporting grounds. By 2010, the Minister for Education, Julia Gillard, had also released the BER National Coordinator's Implementation Report that outlined the progress of these initiatives in the first eight months of the program (DEEWR 2009).

Hasty consultation and implementation, spurred by the GFC, led to damaging public claims of rorts by unscrupulous providers creating perceptions that could have played a part in Rudd's declining popularity and subsequently his demise as Prime Minister. By early 2010, complaints about the BER had intensified in the popular press, leading eventually to polarised views in the professional press. To counter what the government perceived to be a media 'beat-up' led by The Australian newspaper and whilst claiming there were only 100 complaints about the BER despite 2400 projects under way, the Education Minister established an 
implementation task force to investigate claims of overcharging and excessive project management fees. The task force was allocated \$13.2 million in the 2010 budget, redirected from the administrative costs of the BER and taken on a proportionate basis from the states, territories and private school authorities according to the investigations held in each sector.

Whilst a Commonwealth Auditor-General's report into the $\$ 14.1$ billion primary school building program found that spending was slower than anticipated, there were far more damaging claims of rorting by those involved in the building industry. An independent inquiry into the BER claimed that government schools were being charged nearly double the standard commercial rates (Hannaford 2010). Craig Mayne, a former civil engineering design draughtsman, conducted an analysis over a 15-month period of the building conducted under the BER banner in New South Wales and found projects were significantly more expensive than they needed to be. He claimed Catholic and independent schools achieved good value for money but that costs had been higher in government schools. Based on Rawlinson's Australian Construction Handbook, Mayne argued that half the cost could have achieved a credible project with a profit margin. Even the signage was criticised, and the whole affair proved to be disappointing for a government that, as some saw it, had had 'the prescience and bold action to save the nation from the experience of other advanced countries in the Global Financial Crisis' (Taylor and Uren 2010:229).

Certainly, the infrastructure expenditure involved some waste of public monies due to poor implementation by some state government school systems (notably in New South Wales) compared with other parts of the school sector. Increased local autonomy in determining priorities for the school sector might have led to more effective outcomes, and appears to have done so in the non-government sector. Certainly, greater efficiencies were possible. A hasty stimulus response led to unmonitored implementation and attracted unscrupulous providers. Some cited faulty implementation as a necessary feature of the circumstances in which the stimulus spending arose. Others highlighted Rudd's centrist disorganisation emanating outwards (Taylor and Uren 2010:147). Still others pointed to the lack of coordination between state and federal regulatory frameworks, laying blame on the tendering process and excessive administration. Overall, the criticism was damaging but Julia Gillard overrode claims of incompetence by launching investigations - a tactic that had eluded her environment ministerial colleague.

The DER, entailing the commitment of a computer or laptop for every year nine12 student in the nation, also sustained heavy criticism. Some commentators asked if schools had the educational capacity to make the best use of this technology (Moyle 2010). Like the BER, for the DER, infrastructure spending alone on improved technology would not necessarily make a revolution. New breakthroughs in technology and greater connectivity required more than a 
massive spend; they required a fundamental shift in the approach to learning. In addition, a roll-out of the infrastructure targeted to those areas with the greatest need would have enabled funds to be diverted to other pressing local problems within the school sector. But of course, more time would have been needed to delineate local problems, consult widely and enable timely solutions - and time was something that the government felt it could not afford.

The complexity of commonwealth-state school arrangements no doubt created complications. By September 2009, the states and territories had taken different approaches to the computers for schools program. In New South Wales, for example, year nine students would be able to keep their laptops if they completed year 12. Under the Commonwealth model, there would be a need to equip every state high school with new technology every year. This would likely be a costly and short-term exercise if some states chose to allow their students to keep computers.

Transparent accountability was perhaps the only intervention that had the potential to transform the educational landscape. This feature of Labor's educational policy was informed in part by Gillard's visits to the United States and, to a lesser extent, to the United Kingdom. Two programs were cited as making schools transparent and accountable: the National Assessment Program for Literacy and Numeracy and the My School web site.

The Rudd government had argued that school standards were not high enough and that failing schools had to be held accountable. Rudd urged parents unhappy with an under-performing school to vote with their feet and move to a more successful one. After many years of planning and at times inaction under the Howard government, the National Assessment Program-Literacy and Numeracy (NAPLAN) commenced in schools in 2008 with all students in years three, five, seven and nine nationally assessed in reading, writing, language conventions and numeracy. The My School web site developed by ACARA was launched on 28 January 2010 and had more than nine million hits on the first day. The web site included a report card for almost 10000 Australian schools, with each report card providing 'rich' performance and contextual information about individual schools. The web site listed statistically similar schools as the point of comparison. Each school had a grading on the Index of Community Socio-Educational Advantage (ICSEA), calculated using students' residential addresses and information from the Australian Bureau of Statistics.

On 7 February 2010, the Minister for Education announced an additional \$11 million for 110 schools identified through the My School web site as needing help to ensure students improved their literacy and numeracy. By this stage, there was a divided response to the intention and method of NAPLAN and the My School web site. The main arguments supporting the process were based 
on the principle that national assessments represented crucial accountability features of high-performing education systems and the transparent comparison of school performance was needed for resource allocation to help reduce inequality (see Jensen 2010).

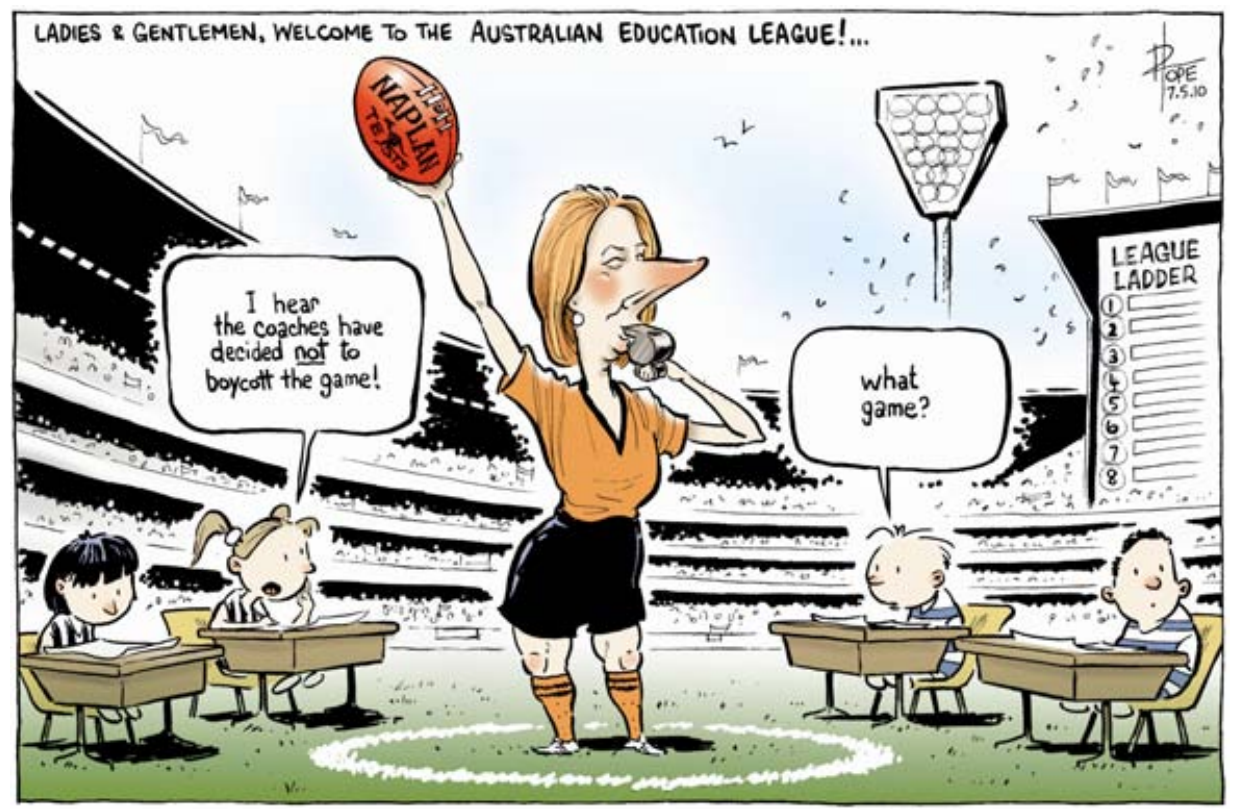

Source: David Pope, The Canberra Times, 7 May 2010

The rhetoric was to make every school transparently accountable for its literacy and numeracy performance. There was, however, little critical analysis of this concept. Accountability - a key concept in quality assurance amongst professional bodies - usually involves a blend of internal (self-review) and external (inspection) indicators. If quality is high, public resources would be wasted on a massive bureaucratic exercise with little risk for high-performing schools. The policy also lacked a rigorous evidence base, with little sustained research showing long-term outcomes for schools - ironic given that evidencebased policy was Labor's strong motif in the early days of government.

Labor policy was not particularly innovative or tailored to the Australian context. It was derived largely from the United Kingdom and, to a lesser extent, the United States. Reports on the effectiveness of similar schemes in the United Kingdom and the United States were mixed. In the United Kingdom, an analysis of the effectiveness of the similar National Literacy Strategy implemented in 1998 showed that too much testing narrowed the curriculum, robbing students from lower socioeconomic backgrounds of the broad-based education needed to break cultural barriers to disadvantage. Adam Curtis (2008), in an influential 
series of BBC documentaries, The Trap, maintained rich parents moved to areas with the best schools, pushing up house prices and exacerbating social segregation.

In the United States, there were similar views on the 'No Child Left Behind' (NCLB) legislation, and Joel Klein's New York State program setting targets for schools and consequences for failure (US Department of Education 2001). Diane Ravitch (2010), Research Professor of Education at New York State University and once a proponent of the scheme, cited the perverse effects of focusing on the test. Since the law permitted every state to define 'proficiency' as it chose, many states announced impressive gains. But the states' claims of improvement were contradicted by the federally sponsored NationalAssessment of Educational Progress (NAEP). The states responded to NCLB by dumbing down their standards so that they could claim to be making progress. Because the law demanded progress only in reading and maths, schools had an incentive to show gains only in those subjects. Meanwhile, there was no incentive to teach the arts, science, history, literature, geography, civics, foreign languages or physical education. Transparent accountability had seemingly produced graduates who had been drilled regularly on the basic skills yet complaints continued about the poor preparation of university entrants (Bamford 2010; Boston 2009).

Despite the huge outlay on infrastructure, the Rudd government avoided addressing the underlying structural inequities in the educational system. Reform of the funding model was intentionally deferred until the assumed second term of a Labor government to avoid the backlash that Mark Latham's policy reform of school funding had suffered at the previous election. According to commentators in the school sector, whilst 'equity and excellence' had been superficially tackled, the sector lacked the reforms needed to address the complex and inconsistent forms of funding and governance arrangements that entrenched sectoral division. The burden of educating those with the greatest need fell on a relatively small proportion of schools (Keating 2010). The policy setting also failed to address the inequities set up by the funding of private schools (Caldwell 2009). Some argued that public funding needed to be limited for those schools that practised religious training and/or restricted access on social or economic grounds. The different resourcing patterns for state and private schools also entrenched further inconsistencies and inequities in school resourcing arrangements in Australia. 


\section{The tertiary sector: transformation or tinkering?}

A failure to address structural fault lines could also be found in the Rudd government's approach to reforming the tertiary sector. As a result, incompletely thought-through policy, conflicting agendas and confused objectives were evident, creating a lack of focus for many policy initiatives. Hurried and uncoordinated consultation and implementation also undermined the attainment of objectives for many initiatives.

\section{The higher education sector}

In March 2008, Julia Gillard commissioned Professor Denise Bradley, former Vice-Chancellor of the University of South Australia, to conduct a broad-ranging review of higher education and its fitness for purpose in meeting the needs of the Australian community and economy. The report's 46 recommendations were released in December 2008, underpinned by a predominantly economic rationale that tied higher education to workforce productivity and skills shortages (DEEWR 2008).

In the lead-up to the Bradley Review, Gillard had criticised the higher education sector's participation rates, particularly of those from disadvantaged backgrounds, and also unacceptably low completion rates, estimated later by Bradley to be 72 per cent. Further justification for change was provided by the nation's slippage in degree attainment from seventh to ninth in the previous 10 years amongst twenty-five to thirty-four-year-olds. The academic workforce was ageing and the nation's best were being lured overseas, it was said. Student-staff ratios had climbed from 13:1 in 1990 to 20:1 in 2006; student satisfaction with higher education teaching was static, and seemingly lower than in the United Kingdom and the United States. Public investment in higher education - as distinct from student fees and contributions through the Higher Education Contribution Scheme (HECS) - was said to be amongst the lowest of the members of the Organisation for Economic Cooperation and Development (OECD) (DEEWR 2008). The Bradley recommendations promised improved indexation and infrastructure upgrade funding, leading to optimism in the sector that higher education would at last receive the funding needed to maintain facilities and quality.

The government responded in May 2009 with its twin platform of equity and excellence in higher education, detailed in the policy document Transforming Australia's Higher Education System. Expansion of the sector was the order of the day; the sector would move to a demand-driven funding system for domestic higher education students, worth \$491 million over three years, to be phased in through transitional raising of the volume cap on places in 2010 and 2011. 
Recognised providers could enrol as many eligible students as they wished. The government set the national attainment target at 40 per cent of twenty-five to thirty-four-year-olds educated to bachelor-level degree or above by 2025 . Social inclusion was another key agenda with at least 20 per cent of higher education enrolments to be from low socioeconomic backgrounds by 2020. Equity funding was to constitute about 2 per cent of teaching and learning grants, increasing to 3 per cent in 2011 and 4 per cent directed to outreach and retention by 2012 .

Courtesy of the GFC, university infrastructure was the biggest winner with a nearly $\$ 3$ billion capital injection over three years in the form of the Education Investment Fund. Recurrent funding was to be adequately indexed with revised indexation, totalling \$578 million, to be introduced from 2012 (departmental officials euphemistically referred to 2010 as a 'gap' year for funding). An extra $\$ 80$ million a year - and possibly a new national university for regional areas - was promised to improve higher education provision in remote regions, including through collaboration with TAFE.

Gillard claimed that the government was supporting the higher education and research sectors at a cost of an additional $\$ 5.4$ billion over four years and would commit further resources over the next 10 years. This included funding of $\$ 1.5$ billion for teaching and learning, \$700 million for university research, $\$ 1.1$ billion for the Super Science initiative and \$2.1 billion from the Education Investment Fund for education and research infrastructure.

Quality was to be paramount, and would certainly be an essential element in a demand-driven higher education world. A new national super-regulator would be set up to oversee accreditation and quality assurance, based on standards and outcomes, of public and private institutions by 2010. Universities as institutions would become, for the first time, subject to accreditation standards set by the regulator but would still accredit their own courses. The promise was that regulation would be one step removed from government, but applied more evenly and objectively across both public and private providers, including international universities establishing an Australian presence and TAFE providers seeking to offer degree-level qualifications. Significant funding for structural change would be introduced to a total of $\$ 402$ million, which could potentially include new models of education. The Sustainable Research Excellence in Universities was to be introduced with a \$512 million increase in funding for the indirect costs of research.

The sector's initial enthusiasm for the governmental agenda gradually palled. For example, the Vice-Chancellor of the University of Canberra, one of the authors, questioned the attainment target, arguing that the sector had already been on track for 40 per cent well before 2025. Simply by raising the cap on places and providing more funded places under the existing system, the sector would easily 
achieve the target, effectively removing the need for partial deregulation of the system. Parker (2009) argued for an easy achievement of targets by addressing the higher education and vocational education and training interface, targeting those with diplomas and advanced diplomas.

Many criticised the ensuing consultation and implementation process (see Slattery 2010a). Four ministers - Julia Gillard (Education), Kim Carr (Science and Research), Simon Crean (Trade) and Nicola Roxon (Health)- -had significant reform agendas, some of which conflicted with the recommendations and direction of the Bradley Review. At the institutional level, Labor's reforms were to be negotiated in individualised mission-based compacts with each university. Mission-based compacts would take effect from 2011 as agreements between universities and the Australian government, detailing public funding commitments and reciprocal institutional commitments. They would support universities 'to pursue their distinctive missions and to contribute to the Australian government's aspirations for the higher education sector as a whole' (DIISR 2010).

Besides conflicting agendas, there were confused objectives. Whilst compacts would be an individual exercise, the sector would respond uniformly to the government's proposed indicator framework for funding teaching and learning. A standardised suite of measures was proposed to assess all universities. Participation and inclusion indicators specified agreed increases. There were to be student experience, student attainment, and quality of outcome measures. Whilst the government claimed the sector was responsive to the reform agenda, some suggested a contradiction between the proposed indicator framework and the compact discussions with individual institutions, wondering how standardised indicators could be used across the sector, yet individual compacts foster institutional diversity. If institutions were to achieve their unique missions, they needed institutionally determined indicators, tailored to unique circumstances. To add to the complexity, the Commonwealth had also emphasised partnerships in the funding provisions to address low SES numbers. Yet, there was little encouragement of linked compacts or any collaborative activity beyond forming partnerships in various grant-getting exercises.

Vice-chancellors interpreted this sense of dissonance as being the product of the Rudd government's split of responsibility for education (DEEWR, under Gillard) and research (DIISR, under Carr), with the two ministers happening to have different views about the relative priorities of sectoral performance and individualised missions for institutions.

In tandem, the highly prescribed draft guidelines from the Tertiary Education Quality and Standards Agency (TEQSA) were released for comment. The guidelines comprised nine 'hard to argue' standards concerning mainly sound 
financial management, quality student standards, teacher quality and the like. The 87 requirements accompanying them, however, were at a level of detail likely to require intensified reporting and bureaucratic process in universities. The standards and requirements showed little regard for the distinction between the existing self-accrediting and non self-accrediting institutions. Some felt they infringed institutional autonomy too much. Although departmental officials claimed the standards were not intended for use against existing universities, there was a growing sense of unease about their very existence. A regulatory zeal was found in some recommendations that prescribed process rather than outcomes - akin to the process-driven approach said to be associated with the Australian Universities Quality Agency (AUQA), which TEQSA was replacing (Email correspondence, DVCA Executive).

Overall, the sector responded well to the underlying sentiments of the government's response to Bradley, but as time wore on it became concerned about the internal contradictions and complexity of the reforms, as well as being sceptical about whether the Public Service could actually keep up with and implement them. But a more fundamental concern also began to take hold-namely, whether higher education policy was actually being developed consistently with vocational education policy, despite the prevalence of words such as 'convergence', 'integration' and 'alignment'.

\section{The vocational education and training sector}

The COAG skills target agreed from 1 January 2009 was to halve the proportion of twenty to sixty-four-year-olds without qualifications at Certificate III level by 2020, and double the number of higher vocational education and training (VET) qualification completions by 2020. Although these targets for VET qualifications were described by the government as complementing higher education attainment goals, they could not obviously be meshed with them, if only because the population groups differed, with the VET targets related to twenty to sixty-four-year-olds and the higher education (HE) targets related to twenty-five to thirty-four-year-olds (Parker 2009)

It was widely understood that smooth transitions from VET to HE would be needed for the government's participation agenda to succeed. Appropriate regulation between the two sectors would also be needed to ensure quality educational provision, but there were many hurdles of history, practice, culture and jurisdiction to overcome. Some called for a unified set of national tertiary education protocols for eligibility, approval and transition. They suggested a focus on non-VET diplomas and advanced diplomas to resolve the tension between the competency (VET) and knowledge (HE) basis of the two sectors (Ross 2010). A milestone statement of agreement from Universities Australia and 
TAFE Directors Australia (TDA) proposed unified protocols covering the new tertiary sector. At the same time, a study showed that TAFE had only 12 per cent low SES students from 2008 figures - significantly behind the 17 per cent found in higher education (Hare 2010). Low SES students were more likely to be found in Certificate I, II and III levels, making the transition less likely to be accessible to university entrance.

The quality agenda for VET was also unlikely to mesh with higher education. Pam Caven, CEO of TDA, stated that the separate evolution of national regulators for the TAFE and university sectors could lead to incompatible models (Ross 2010b:8). A joint statement by TDA and Universities Australia proposed diploma and above as a marker of tertiary institutions in line with the OECD's International Standard Classification of Education. This would make clear the operating boundaries and protocols for the tertiary sector particularly if noncompetency-based diplomas were included in VET provision. The TAFE sector argued for overlapping board membership, compatible statutory objectives and consistent conditions of service. The TDA-UA statement asserted that opportunities should be made for students to move in both directions. The Education Minister expressed a wish for TEQSA and the VET regulator to merge in 2013 but COAG and the Ministerial Council for Tertiary Education and Employment had not agreed. Others queried how seamless this approach could be with VET required to have a standards council as well as a regulator, unlike the university sector.

A key thread in the VET-HE meshing was the Australian Qualifications Framework Council (AQFC). In 2009, the government commissioned the AQFC to improve the articulation and connectivity between the university and VET sectors to enable competency-based and merit-based systems to become more student focused. Yet there seemed to be little coordination with standards set by TEQSA, and the proposed performance indicator framework. To add to the mix, the Commonwealth minister announced that the ambit of Skills Australia would expand to encompass the full scope of Australia's labour-market needs, to give advice to the Commonwealth about the effectiveness of both the university and the VET systems in meeting the broad range of Australia's skill needs.

Despite extensive policy work under the remit of COAG's Productivity Working Party, reforms in the VET sector were hard fought, and achievements fairly limited. In part this related to the attempt by the Commonwealth to adopt the reforms in the Victorian VET sector and apply them nationally despite the unwillingness of other states to do so. As a consequence, big spending reform packages that had occurred in schools and higher education were not undertaken in VET. Prior to the 2010 federal budget, funding for VET had not been as generous as for the school and higher education sectors. The 2010 budget redressed, to some extent, the lack of new spending on the VET sector by the 
Labor government since taking office despite their often stated 'productivity' mantra. The Minister for Education, in a speech to the Big Skills Conference (Gillard 2009), claimed the government had made a strong start to improvements in the VET system by opening the multibillion-dollar Education Investment Fund to universities and VET institutions alike, so as to invest in the capital requirements of further education providers generally. In December 2008, the government launched the $\$ 500$ million capital fund for VET and community education in order to improve the quality of teaching and learning right across the system. It also funded the Trade Training Centres in Schools Program by $\$ 2.5$ billion over 10 years to enable all secondary schools to access new trade facilities in traditional and emerging fields. These initiatives were, however, shared with the school and university sectors.

In the 2010 budget, the government announced a suite of measures totalling $\$ 660$ million aimed at expanding and improving VET to address skills shortages (Slattery 2010b). Vocational education and training would create 39000 training places in high-demand skills (\$200 million) and 22500 apprenticeship start-ups (\$120 million) to tackle language and literacy difficulties for 140000 Australians. The greatest beneficiaries were those seeking diplomas and those apprentices and adults with poor literacy and numeracy. This funding would be dependent on the sector improving quality and transparency. A new My Skills web site would be created as well as a new regulator for VET at a cost of $\$ 93.3$ million.

The funding was seen to come largely at the expense of the university sector, though sparing The Australian National University-a commonwealth university and the alma mater of Prime Minister, Kevin Rudd — which benefited by $\$ 112$ million over four years to establish public policy, national security and China initiatives. In a statement provided by Universities Australia, the 2010-11 budget increased the official level of higher education from $\$ 7.5$ billion to $\$ 8.1$ billion-broadly in line with 2009 commitments. The Education Investment Fund provision was, however, reduced by $\$ 130$ million from the previous budget provisions. Universities Australia declared that the 2010-11 provision 'begins the decline in public higher education funding as a share in GDP, taking Australia's provision further below OECD norms' (Withers 2010).

\section{A comparison with the United Kingdom and the United States}

Rudd's legacy needs to be referenced not only to his considerable achievements but also to Howard's and Blair's performances on education in their (longer) first terms. It is hard not to conclude there were honourable intentions for 
education by the Rudd government but administrative shortcomings and a lack of public relations know-how gave its critics ammunition and undermined public confidence.

For the most part, Labor's education funding addressed the long-term neglect of the Howard years (1996-2007). Howard, in his first term, used a budget shortfall, which he blamed on the previous government, to implement a series of massive cuts to education. Whilst known for its middle-class welfare, the Coalition increased university fees (under the HECS loan system), and introduced full 'up-front' fees for some students. In following years, when the budget surplus reappeared, the money was applied to other purposes, such as a private health insurance rebate or income tax cuts for people on high salaries. This represented a reduction in real terms of education funding. The hallmark of Howard's full term was an increased emphasis on private delivery of what had previously been public services. ${ }^{1}$ In 1995, Australia was already at the lower end compared with other OECD countries in terms of the public share of tertiary education spending - 13 points below the average. After another decade, though, the public share had dropped to less than half - 48 per cent-and Australia was then 26 points below the average. In 2005, Australia spent 0.8 per cent of GDP on tertiary education compared with an average of 1.1 per cent. In other words, Australian expenditure would have had to increase by about 35 per cent to bring it up to the OECD average. In the other countries for which we have data, public spending on tertiary education was up by 30 per cent in real terms over the decade 1995-2005. Only in Australia did it decrease.

Claims of a lack of coherence and confused objectives are shared with Tony Blair's first term in government. In the lead-up to the election, Blair stated that his top three priorities were 'education, education, education'. During the first two terms of the Blair government, there were massive changes in almost every aspect of education. The most important initiatives in Blair's first term included the National Literacy and Numeracy Strategies to ensure that all primary children met agreed targets, the establishment of a Social Exclusion Unit within the Cabinet Office and the creation of the General Teaching Councils. The structure and funding of schools and education for fourteen to nineteen-yearolds were also targeted (Walford 2005).

Focus in the first half of the Blair government was on the schools standards agenda, the rationale being that general improvement in student attainment would significantly improve the economy. There was evidence that it had

\footnotetext{
1 This comment has also been made in relation to a range of services across health, education, employment support and child care, where publicly provided services were increasingly being delivered through private mechanisms (see, for example, Aulich 2010).
} 
worked in the first term. But during the second term the rise in attainment had plateaued, with commentators stating that much of it was due to teachers teaching to the test.

Blair's second term promised increased investment in higher education, and the expansion to 50 per cent of the proportion of people under thirty with a higher education experience. It also stressed the government's desire for diversity of mission within higher education, emphasising teacher quality, the raising of top-up fees and the introduction of an independent regulator to negotiate contracts with universities.

There is a striking similarity with Australia in the continuing debate in the United Kingdom about contradictions between different elements of Blair's policy. Some aspects of Blair's policy were aimed at reducing inequity and others were aimed at the opposite. Some policies led to centralisation, some to localisation. Like Rudd's policies, in the United Kingdom, the sheer variety and number of separate initiatives have led to a sense of overall incoherence (referred to as 'initiativitis' in Chapter 1 or 'a government of announcements' in Chapter 2 of this volume).

To a lesser extent, specific US initiatives, mostly in New York State, were also a source of Labor's education initiatives. 'Teach for Australia' was a program based on the 'Teach for America' program; NAPLAN and the My School web site (<http://inside.org.au/my-school-and-your-school/>) have already been cited as programs introduced in New York by Joel Klein; and Minister Gillard based the leadership development program for school principals on the leadership academy created by Klein. Whilst the United States provided ideas for specific initiatives, it was not, however, as extensively influential as the United Kingdom.

\section{Conclusion}

A massive spend on infrastructure does not make a revolution. Geoffrey Blainey (ABC 2009) has argued that the real education revolution began in 1873 when Victoria mandated compulsory education for all, lasting until age thirteen or fourteen (soon followed by South Australia and New South Wales). Primary schools needed to be built throughout the states and, at the time, this was progressive when compared with nations in Europe, in that it was a radical law against child labour. Rudd's education revolution is hardly a revolution in comparison with these initiatives. Similarly, secondary education experienced great growth after World War II, as did the university sector, which grew substantially when the sector opened its doors to returning servicemen and women, effectively beginning the tertiary trajectory from elite to mass education in Australia. 
The education revolution was a missed opportunity for structural reform in and across all sectors covered in this chapter. Conflicting economic, educational and equity agendas led to confused objectives and hasty implementation and, ultimately, publicly damaging outcomes. Conflation of the education and economic goals from investment in education led to a situation in which neither was addressed adequately. Considering the expense of the programs relative to possible outcomes, there has been considerable wastage. Greater engagement with local issues by the Rudd government coupled with increased local autonomy for spending might have allowed greater effectiveness and certainly greater efficiencies.

There was not a long-term vision for the sector in the education revolution. In the school sector, the state-private funding conundrum was not addressed. In the tertiary education sector, the VET-HE transition zone remained unclear, as did the relationship of private providers to a national quality system. Overall, confused agendas and conflicting objectives left an awkward experience for students traversing institutional settings that do not mesh and with poor integration between targets, standards and regulation.

There is likely to be greater 'transparent accountability' in the repetitive motifs of the Labor government-My School, My University, My Skillstogether with their perverse effects related to the inaccurate use of statistics for funding, further cultural impoverishment for disadvantaged students and the entrenchment of social segregation. An expensive and bureaucratic system will be needed to gather a huge variety of data.

The main focus on infrastructure and transparent accountability in the education revolution missed an important opportunity to address all of the above issues, which remain unaddressed. The various reviews conducted also missed the opportunity to examine the radical transformation of learning in the future created by the rapid acquisition of knowledge and the incredible pace of technological development. Further, the failure to come to grips with international education - one of Australia's greatest exports - has done little to stimulate expenditure on aspects of the education system that are likely to generate more income.

By necessity, haste in the policy process meant a diminution of consultation and implementation. It is unlikely that, when conceived in haste, all buildings were 'fit for purpose' or even needed. The stipulation of infrastructure to address perceived need might have meant real need was not addressed elsewhere.

In his tearful farewell address as Prime Minister, Kevin Rudd indicated that, under his leadership, the education revolution topped a litany of his 
achievements. Although paved with good intentions, the education revolution was not a revolution and was likely to be a missed opportunity to significantly advance student learning outcomes in the Australian educational sector.

Carole Kayrooz is Deputy Vice-Chancellor (Education) at the University of Canberra.

Stephen Parker is Vice-Chancellor at the University of Canberra.

\section{References}

Aulich, C. 2010. 'Privatization in service delivery: lessons from Australia', in T. Moon Joong (ed.), The Service Sector Advancement: Issues and implications for the Korean economy, Korean Development Institute, Seoul, pp. 155-71.

Australian Broadcasting Corporation (ABC) 2009. 'Education Revolution?', Counterpoint, 28 September, <http:/www.abc.net.au/rn/counterpoint/ stories/2009/2698310.htm>

Australian Curriculum, Assessment and Reporting Authority (ACARA) 2010. My School, Australian Curriculum, Assessment and Reporting Authority, Sydney, <http://www.myschool.edu.au/>

Australian Government 2010. Budget Paper No. 3, Commonwealth of Australia, Canberra, <http:/www.aph.gov.au/budget/2010-11/content/bp3/html/ index.htm>

Bamford, P. 2010. 'Teaching to the test', Inside Story, 7 April, <http://inside.org. au/teaching-to-the-test/>

Boston, K. 2009. 'Lesson from England on league tables', Education Review, September, p. 7.

Caldwell, B. 2009. 'Education revolution fails grade', The Age, 2 November, $<$ http://www.theage.com.au/national/education/education-revolution-failsgrade-20091101-hrjv.html>

Curtis, A. 2008. The Trap, BBC documentary, < http://video.google.com/videop lay?docid $=404227395387111085 \#>$

Department of Education, Employment and Workplace Relations (DEEWR) 2008. Review of Australian Higher Education, Department of Education, 
Employment and Workplace Relations, Commonwealth of Australia, Canberra, <http://www.deewr.gov.au/highereducation/review/pages/ reviewofaustralianhighereducationreport.aspx $>$

Department of Education, Employment and Workplace Relations (DEEWR) 2009. National Coordinator's Implementation Report, Department of Education, Employment and Workplace Relations, Commonwealth of Australia, Canberra, <http://www.deewr.gov.au/Schooling/BuildingTheEducationRevolution/ Documents/NCIReport.pdf>

Department of Education, Employment and Workplace Relations (DEEWR) 2010a. Nation Building: Economic stimulus plan, Department of Education, Employment and Workplace Relations, Commonwealth of Australia, Canberra, $<$ http://www.deewr.gov.au/Schooling/BuildingTheEducationRevolution/ Pages/default.aspx $>$

Department of Education, Employment and Workplace Relations (DEEWR) 2010b. Digital Education Revolution, Department of Education, Employment and Workplace Relations, Commonwealth of Australia, Canberra, $<$ http://www.deewr.gov.au/Schooling/DigitalEducationRevolution/ HighSpeedBroadband/Pages/HighSpeedBroadbandToSchools.aspx>

Department of Education, Employment and Workplace Relations (DEEWR) 2010c. Trade Training Centres in Schools Program, Department of Education, Employment and Workplace Relations, Commonwealth of Australia, Canberra, < <ttp://www.deewr.gov.au/Schooling/TradeTrainingCentres/ Pages/default.aspx $>$

Department of Education, Employment and Workplace Relations (DEEWR) 2010d. Building the Education Revolution, Department of Education, Employment and Workplace Relations, Commonwealth of Australia, Canberra, $<$ http://www.deewr.gov.au/Schooling/BuildingTheEducationRevolution/ Documents/BERsustainabilityFactSheet.pdf>

Department of Innovation, Industry, Science and Research (DIISR) 2010. Mission-based compacts for universities, Fact sheet, Department of Innovation, Industry, Science and Research, Commonwealth of Australia, Canberra, <http://www.innovation.gov.au/Section/AboutDIISR/FactSheets/Pages/ Mission-BasedCompactsforUniversitiesFactSheet.aspx $>$

Gillard, J. 2009. Speech at the Big Skills Conference, Darling Harbour, NSW, 5 March.

Hannaford, S. 2010. 'Inquiry told of education building program rip-off', The Canberra Times, 20 May, p. 1. 
Hare, J. 2010. 'TAFE no haven for low-SES students', Campus Review, vol. 20, no. 7 (April), p. 1 .

Jensen, B. 2010. 'NAPLAN tests help champion equality in the classroom', The Age, 15 April, <http://grattan.edu.au/publications/025_jensen_oped_age_ education.pdf $>$

Keating, J. 2010. Resourcing for Schools. A proposal for the restructure of public funding, The Foundation for Young Australians, Melbourne, <http://www. fya.org.au/what-we-do/research/research-publications/>

Moyle, K. 2010. 'So you want a revolution', Education Review, May, pp. 23-25.

O'Keeffe, D. 2010. 'Building capacity, but slowly', Education Review, May, p. 1.

Parker, S. 2009. 'The Bradley review: unfinished business', Australian Financial Review Higher Education Conference, Sydney, 9-10 March.

Ravitch, D. 2010. The Death and Life of the Great American School System: How testing and choice are undermining education, Basic Books, New York.

Ross, J. 2010a. 'It's time for unified protocols', Campus Review, vol. 20, no. 8 (27 April), p. 1.

Ross, J. 2010b. 'Fractured regulation threatens tertiary integration', Campus Review, vol. 20, no. 8 (27 April), p. 8.

Rudd, K. and Smith, S. 2007. The Australian Economy Needs an Education Revolution, Australian Labor Party, Barton, ACT.

Slattery, L. 2010a. 'Reforms recipe for mediocrity, not excellence', The Australian, 10 May, p. 39.

Slattery, L. 2010b. '\$660m will benefit Gillard's battlers', The Australian, 12 May, p. 8.

Taylor, L. and Uren, D. 2010. Shitstorm, Melbourne University Press, Carlton, Vic.

US Department of Education, 2001. No Child Left Behind, US Department of Education, Washington, DC, < http://www2.ed.gov/nclb/landing.jhtml>

Walford, G. 2005. 'Education and the Labour government: an evaluation of two terms', Oxford Review of Education, vol. 31, no. 1 (March), pp. 3-9.

Withers, G. 2010. 2010/11 higher education budget analysis, Universities Australia email communication to Australian university executive. 